\title{
PEMBUATAN DESAIN RAMBU LALU LINTAS UNTUK MENGOPTIMALISASI PERILAKU TERTIB PENGGUNA JALAN DI TUBAGUS ANGKE, JAKARTA BARAT
}

\author{
Margaretha Sandi ${ }^{1}$, Theresia Budi Jayanti ${ }^{2}$ \\ ${ }^{1}$ Jurusan Teknik Arsitektur dan Perencanaan, Universitas Tarumanagara \\ Email: m.architect22@gmail.com \\ ${ }^{2}$ Jurusan Teknik Arsitektur dan Perencanaan, Universitas Tarumanagara \\ Email: theresia.bj@gmail.com
}

\begin{abstract}
ABSTRAK
Pelanggaran yang terjadi pada infrastruktur transportasi beragam, dari parkir liar kendaraan pada tepi jalan raya yang mengganggu alur pedestrian, atau perilaku pengemudi yang menghiraukan signage rambu-rambu lalu lintas, sering terjadi pada kota Jakarta. Dari berbagai ketidaktertiban lalu lintas yang terjadi dapat menimbulkan efek keberlanjutan, satu kasus diantaranya ialah perilaku pengemudi kendaraan yang cenderung berhenti pada zona zebra cross, atau bahkan sudah melewati jauh dari zona tersebut pada perhentian lampu merah. Persimpangan jalan Tubagus Angke merupakan salah satu persimpangan yang padat, banyak dilalui kendaraan berbagai jenis (angkot, mobil pribadi, sepeda, pejalan kaki, pedagang dengan gerobak, dll). Pada persimpangan Tubagus Angke ini juga banyak terjadi pelanggaran terutama di area sekitar lampu pemberhentian dan zebra cross, sehingga sering terjadi kecelakaan. Melalui kegiatan Pengabdian Kepada Masyarakat ini, tim pelaksana berusaha untuk memberikan solusi dalam mengoptimalkan perilaku tertib masyarakat di perempatan jalan melalui instalasi desain optimalisasi rambu lalu lintas (khususnya zebra cross). Melalui pembuatan desain zebra cross ini, diharapkan para pengguna jalan mempunyai kesadaran akan fungsi zebra cross dan tertib terhadap lampu lalu lintas, terutama pada saat posisi berhenti di persimpangan jalan. Kegiatan pengabdian ini terbagi menjadi 2 tahapan dalam satu rangkaian kegiatan. Pada tahap perencanaan meliputi survey awal, pengukuran, penggambaran serta dokumentasi. Sehingga menghasilkan gambar kerja skalatis yang sudah disesuaikan dengan kondisi real lokasi. Tahap pelaksanaan dilaksanakan melalui pemasangan materi desain pada lokasi. Berdasarkan hasil pengamatan yang dilakukan setelah pemasangan desain zebra cross, terjadi peningkatan perilaku tertib pengguna jalan, khususnya di perempatan jalan pada saat lampu merah menyala.
\end{abstract}

Kata Kunci : perilaku tertib, Tubagus Angke, zebra cross

\section{PENDAhuluan}

Metropolis menggambarkan sebuah kota besar yang didukung oleh infrastruktur yang dibangun sesuai dengan aturan yang telah diberikan. Infrastruktur yang memfasilitasi transportasi memiliki sekian banyak peraturan yang harus diterapkan demi keamanan, keselamatan, ketertiban, dan kelancaran. Keempat aspek tersebut merupakan faktor penting baik untuk pengemudi kendaraan maupun pedestrian yang juga terlibat dalam tata tertib lalu lintas. Menurut Keputusan Direktur Jenderal Perhubungan Darat: SK.43/AJ 007/DRJD/97, Zebra cross merupakan fasilitas penyeberangan yang ditandai dengan garis-garis berwarna putih searah arus kendaraan dan dibatasi garis melintang lebar jalan. Zebra cross ditempatkan di jalan dengan jumlah aliran penyeberang jalan atau arus yang relatif rendah sehingga penyeberang masih mudah memperoleh kesempatan yang aman untuk menyeberang. Namun masyarakat tidak memiliki kesadaran sehingga sering terjadinya pelanggaran pada prasarana tersebut yang merupakan kebiasaan buruk masyarakat, dalam kasus ini adalah masyarakat kota Jakarta. Salah satu contohnya adalah pelanggaran pengemudi kendaraan yang sering melewati zona zebra cross ketika berhenti saat lampu merah. Hal ini sangat berbahaya bagi pedestrian yang hendak menyeberangi jalan tersebut. Sangat penting untuk memperhatikan atau mengobservasi faktor apa yang membuat pengguna kendaraan tersebut melewati batas zebra cross yang diberikan sehingga menyebabkan sulitnya pejalan kaki untuk menggunakan zebra cross tersebut. 
Isu masalah pengguna kendaraan yang melewati zebra cross memberikan dampak buruk kepada masyarakat terutama pengguna kendaraan yaitu mengikuti perilaku tersebut yang dapat menjadi habit atau kebiasaan buruk masyarakat kota terutama kota Jakarta.Upaya pemerintah provinsi DKI Jakarta dalam menanggapi isu tersebut adalah dengan menggunakan sistem kamera pengawas (CCTV) yang terkoneksi dengan ruang kendali Sistem Pengendali Lalu Lintas milik Dinas Perhubungan melalui Jakarta Smart City, serta memberi teguran kepada pelanggar tersebut melalui pengeras suara. Sistem tersebut hanya berlaku pada kondisi persimpangan jalan yang dipasang kamera pengawas. Hal ini membuat kekhawatiran akan kondisi jalan yang tidak terpasang kamera pengawas. Tidak sedikit bentuk upaya yang telah dilakukan, namun belum ada yang untuk mampu mengurangi pelanggaran tersebut. Melalui pembuatan rambu jalan ini, diharapkan para pengguna jalan menjadi sadar akan fungsi zebra cross dan tertib terhadap lampu lalu lintas, terutama pada saat posisi berhenti di persimpangan jalan.

Pelanggaran yang terjadi pada infrastruktur transportasi beragam, dari parkir liar kendaraan pada tepi jalan raya yang mengganggu alur pedestrian, atau perilaku pengemudi yang menghiraukan signage rambu-rambu lalu lintas, sering terjadi pada kota Jakarta. Dari berbagai ketidaktertiban lalu lintas yang terjadi dapat menimbulkan efek keberlanjutan, satu kasus diantaranya ialah perilaku pengemudi kendaraan yang cenderung berhenti pada zona zebra cross, atau bahkan sudah melewati jauh dari zona tersebut pada perhentian lampu merah. Akibatnya, para pejalan kaki menyeberangi jalan di luar zona zebra cross, hingga adaptasi perilaku pedestrian sebagai tanggapan permasalahan tersebut adalah menyeberangi jalanan kapan pun jalanan sepi atau ketika macet di luar zona zebra cross.

Persimpangan jalan Tubagus Angke merupakan salah satu persimpangan yang padat, banyak dilalui kendaraan berbagai jenis (angkot, mobil pribadi, sepeda, pejalan kaki, pedagang dengan gerobak, dll). Pada persimpangan Tubagus Angke ini juga banyak terjadi pelanggaran terutama di area sekitar lampu pemberhentian dan zebra cross, sehingga sering terjadi kecelakaan. Gambar 1, menunjukkan perempatan lampu merah Tubagus Angke, Jakarta Barat.

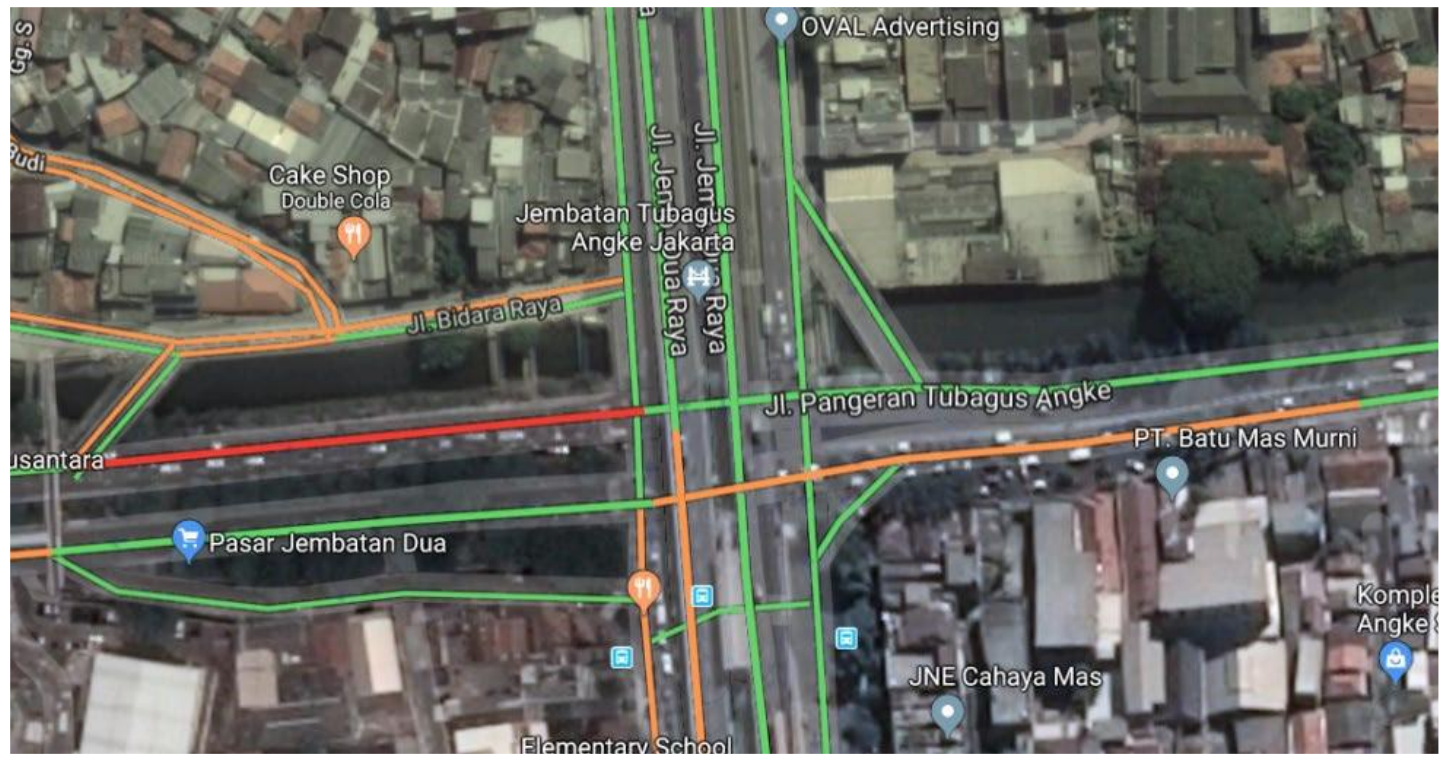

Gambar 1. Perempatan lampu merah Tubagus Angke, Jakarta Barat

Sumber: google maps, 2019 
Parameter warna ini menunjukan situasi kecepatan arus kendaraan, warna hijau melambangkan jalanan yang lancar hingga warna merah yang berarti laju kendaraan macet tidak bergerak. Pada jam tertentu, perempatan lampu merah jalan Tubagus Angke mengalami kemacetan seperti yang tergambarkan pada peta diatas menggunakan notasi garis berwarna, terutama pada jam pulang kantor sekitar pukul 18.00 ke atas. Kondisi eksisting perempatan lampu merah Tubagus Angke pada saat lampu merah menyala, seperti pada Gambar 2.
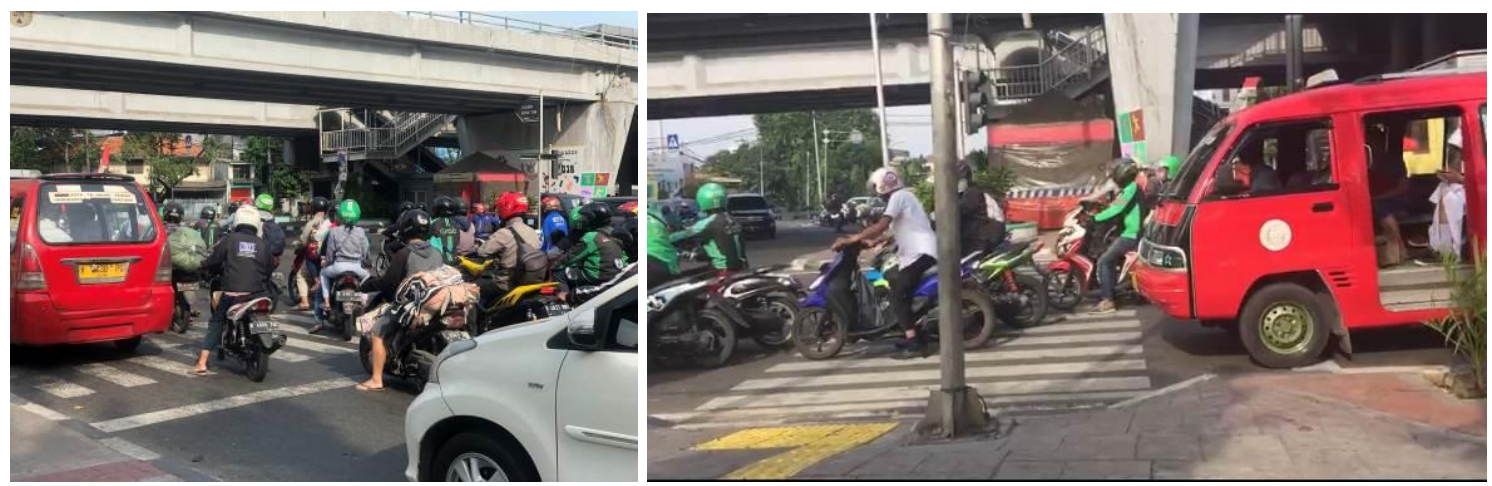

Gambar 2. Kondisi eksisting perempatan lampu merah Tubagus Angke pada saat

lampu merah menyala

Sumber: penulis, 2019

Melalui kegiatan Pengabdian Kepada Masyarakat ini, tim pelaksana berusaha untuk memberikan solusi dalam mengoptimalkan perilaku tertib masyarakat di perempatan jalan. Diharapkan pada pelaksanaan PKM ini dapat terjadi transfer pengetahuan dalam pengungkapan permasalahan, teknik analisis, dan solusi yang langsung diimplementasikan. Disisi lain, pada kegiatan pengabdian ini juga menjadi suatu model musyawarat yang baik, yang diwujudkan dalam tahap FGD (Focus Group Discussion), dimana apa peran serta masyarakat sebagai pengguna jalan, pihak kepolisian dan tim pelaksana PKM.

Luaran fisik dalam kegiatan pengabdian ini adalah hasil instalasi desain optimalisasi rambu lalu lintas (khususnya zebra cross), yang mempunyai tujuan untuk membantu polisi lalu lintas dalam hal upaya menertibkan lalu lintas dan meningkatkan kesadaran pengguna jalan akan tertib lalu lintas. Melalui pembuatan desain zebra cross ini, diharapkan para pengguna jalan mempunyai kesadaran akan fungsi zebra cross dan tertib terhadap lampu lalu lintas, terutama pada saat posisi berhenti di persimpangan jalan.

\section{METODE PELAKSANAAN PKM}

Kegiatan pengabdian ini terbagi menjadi 2 tahapan dalam satu rangkaian kegiatan, yaitu tahap perencanaan dan kemudian tahap pelaksanaan. Pada tahap perencanaan meliputi survey awal, pengukuran, penggambaran serta dokumentasi. Pada tahapan ini akan dihasilkan gambar kerja skalatis yang sudah disesuaikan dengan kondisi nyata lokasi.

Setelah tahap penggambaran selesai, akan dilakukan sosialisasi dan diskusi dengan polisi yang bertugas (masuk kedalam wilayah Polsek Tambora) terkait tentang hasil desain, material dan tahap pemasangannya. Berikutnya hasil gambar kerja tadi akan dicetak di percetakan atau printing dengan media kertas, ukuran dan warna yang sesuai dengan perencanaan. Tahap kegiatan berikutnya berupa pemasangan materi desain pada lokasi. Pada tahap pelaksanaan ini perlu adanya kerjasama antara tim PPM, petugas polisi setempat serta pengguna jalan. Hal 
tersebut dikarenakan lokasi tersebut berada tepat di zebra cross perempatan Jalan Tubagus Angke, sehingga diperlukan pengaturan kondisi lalu lintas.

\section{HASIL DAN PEMBAHASAN}

Menurut Dirjen Bina Marga (1999), zebra cross adalah fasilitas penyeberangan yang ditandai dengan garis- garis berwarna putih searah arus kendaraan dan dibatasi garis melintang lebar jalan. Zebra cross adalah ruang yang dirancang untuk pejalan kaki menyeberang jalan. Crosswalk dirancang untuk menjaga pejalan kaki bersama-sama di mana mereka dapat dilihat oleh pengendara, dan di mana mereka dapat menyeberang paling aman melintasi arus lalu lintas kendaraan. Fungsi dari zebra cross adalah memberikan prioritas kepada pejalan kaki untuk menyeberang dengan aman, sehingga pengemudi mobil maupun motor harus berhenti ataupun memperlambat kecepatannya serta untuk mengurangi kecelakaan yang dapat terjadi. Pelanggaran pada zebra cross terjadi terutama berdasarkan waktu tertentu dimana intensitas kendaraan sedang berada pada tingkat tinggi. Gambar 3, menunjukkan situasi pelanggaran pada eksisting perempatan lampu merah Tubagus Angke pada saat lampu merah menyala (pengamatan jam 06.00-08.00) dan Gambar 4, menunjukkan situasi pelanggaran pada eksisting perempatan lampu merah Tubagus Angke pada saat lampu merah menyala (pengamatan jam 16.00-18.00).

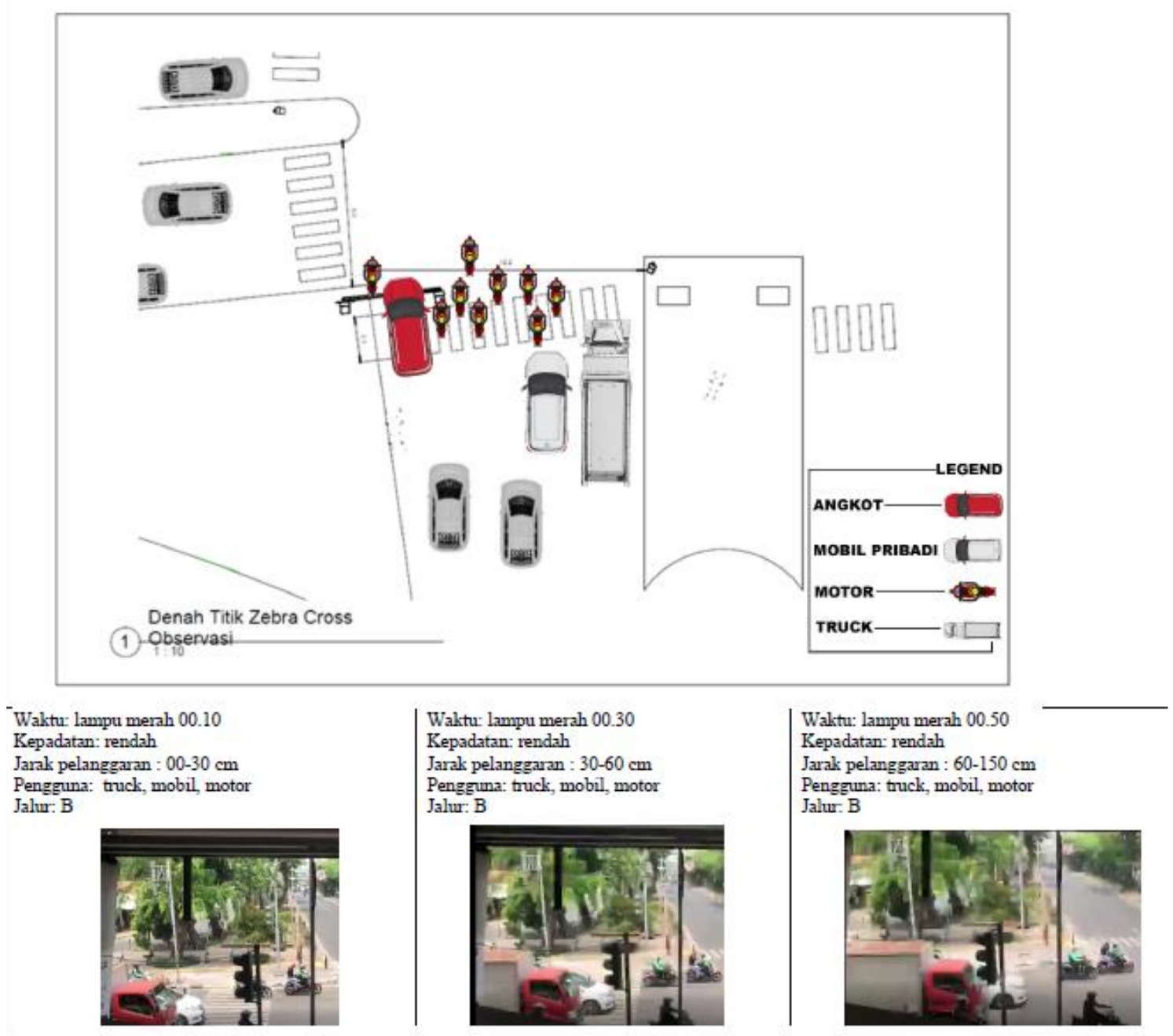

Gambar 3. Situasi pelanggaran pada eksisting perempatan lampu merah Tubagus Angke pada saat lampu merah menyala (pengamatan jam 06.00-08.00)

Sumber: penulis, 2019 


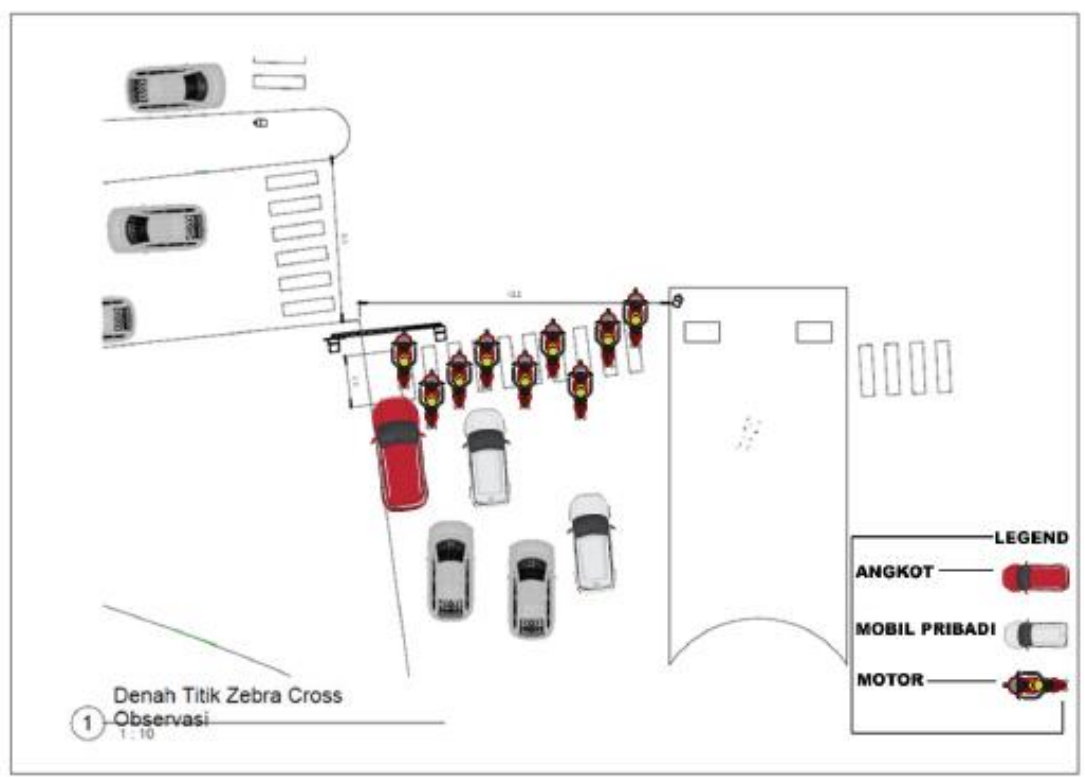

\begin{tabular}{l|l|l}
\hline Waktu: lampu merah 00.10 & Waktr: lampu merah 00.50 & Waktu: lampu merah 01.40 \\
Kepadatan: rendah & Kepadatan: rendah & Kepadatan: tinggi \\
Jarak pelanggaran : $10-60 \mathrm{~cm}$ & Jarak pelanggaran: $60-275 \mathrm{~cm}$ & Jarak pelanggaran: $60-280 \mathrm{~cm}$ \\
Pengguna: motor & Pengguma: motor & Pengguna: motor, angkot \\
Jalur: B & Jalur: B & Jalur: B
\end{tabular}

Gambar 4. Situasi pelanggaran pada eksisting perempatan lampu merah Tubagus Angke pada saat lampu merah menyala (pengamatan jam 16.00-18.00)

Sumber: penulis, 2019

Berdasarkan hal tersebut, diperlukan solusi desain yang dapat diimplementasikan langsung sehingga dapat meningkatkan perilaku tertib pengguna jalan pada saat lampu merah menyala. Berikut merupakan rekomendasi desain sebagai upaya untuk meningkatkan perilaku tertib di perempatan jalan:

\section{Rekomendasi Desain}

Rekomendasi desain pertama berupa tulisan “TETAP PADA JALUR”, sepert pada Gambar 5, yang di pertegas dengan warna merah, dikarenakan warna merah merupakan salah satu warna yang sangat kuat. Filosofi yang terkandung dari arti warna ini berindentikan dengan pertumpahan darah menyisakan luka dan kematian pada zaman perperangan dulu, dimana terbentuklah komunitas anti peperangan dengan laranganan saling melukai yang menggunkan lambang stop berwarna merah. Maka tulisan dengan warna tersebut dapat menimbulkan kesan berani dan pesan yang tegas dan keras untuk berhenti. Gambar 6, menunjukkan ampak Atas Rekomendasi Desain 1.

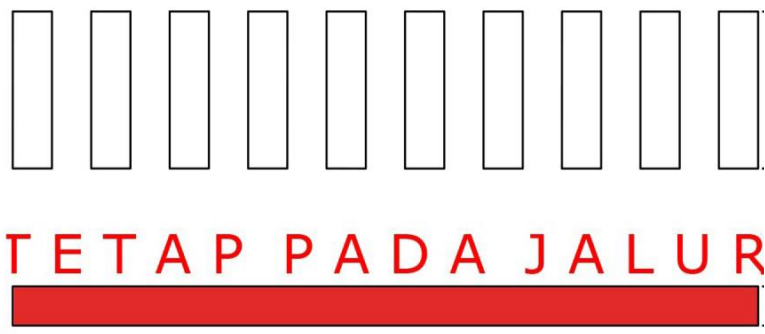

Gambar 5. Denah desain instalasi

Sumber: penulis, 2019 


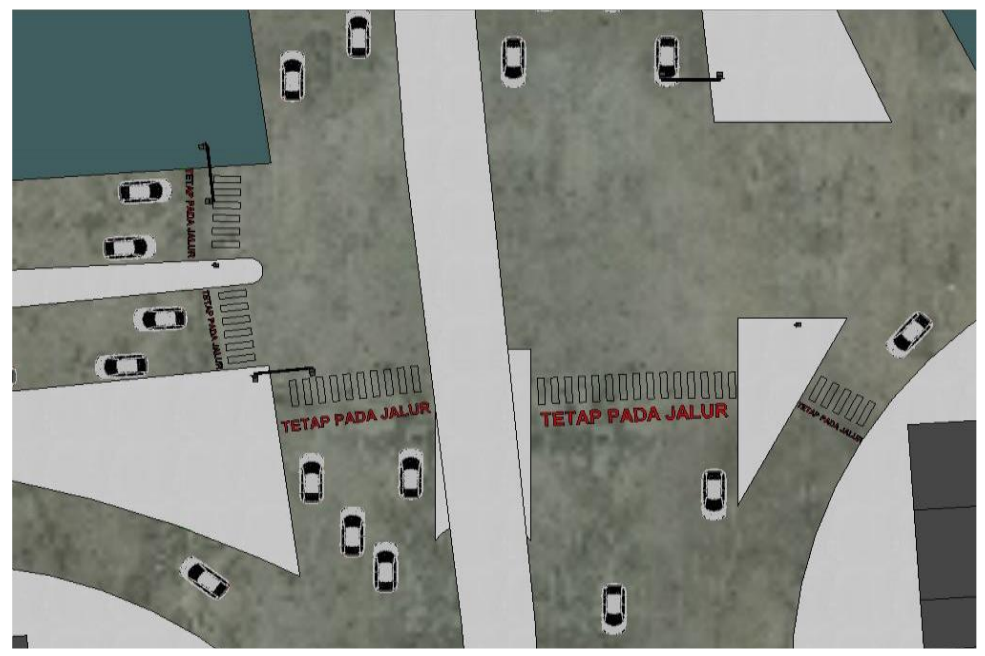

Gambar 6. Tampak Atas Rekomendasi Desain 1

Sumber: penulis, 2019

Menurut Permenhub No 34 Tahun 2014 Pasal 4 ayat 4, mengatakan marka jalan di beri warna merah dikarenakan untuk keperluan dan tanda khusus. Pada lokasi pengamatan kami menggunakan warna merah itu untuk keperluan pedestrian.untuk keselamatan dan keamanan pedestrian saat menyebrangi jalan.Warna merah dapat menarik perhatian pengendara sehingga dari jarak jauh sudah mulai menurunkan kecepatannya sehingga pedestrian dapat menyebrangi dengan aman. Menurut para psikolog yang mempelajari dan menemukan adanya hubungan kuat antara warna dengan tanggapan emosional. Disamping hal tersebut, warna merah dipilih karena dapat membangkitkan rangsangan pada syaraf otomatis yang peka (Luscher dalam Fransisca, 2012).

\section{Tahap Pelaksanaan}

Tahap pelaksanaan diawali dengan tahap pengukuran lokasi PKM yaitu di zebra cross perempatan Jalan Tubagus Angke

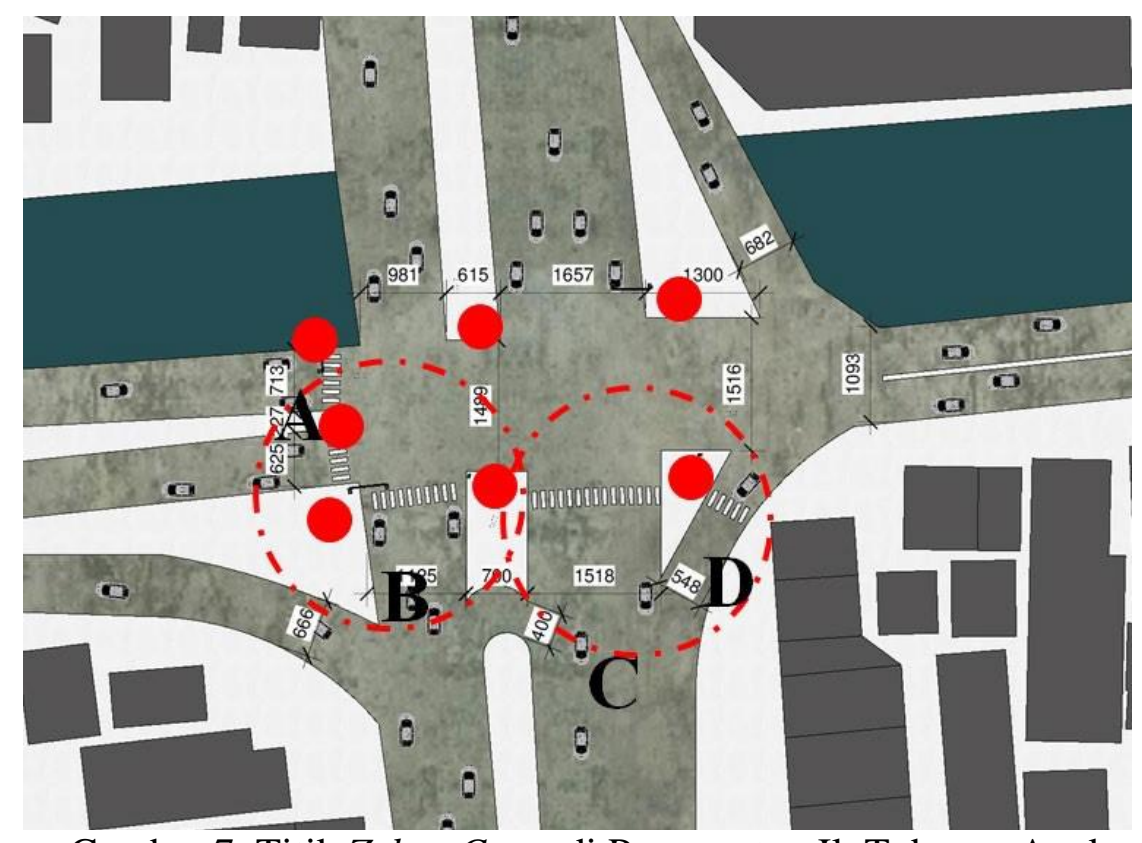

Gambar 7. Titik Zebra Cross di Perempatan Jl. Tubagus Angke

Sumber: penulis, 2019 


\section{Keterangan:}
A. ke arah Pinangsia, Latumenten \& Pluit, ada lampu merah
B. ke arah Pluit \& Pinangsia, ada lampu merah
C. ke arah Latumenten \& Pinangsia, ada lampu merah
D. persimpangan ke arah Latumenten, tidak ada lampu merah

Setelah dilakukan pengukuran, maka perlu dilakukan pembuatan gambar kerja beserta keterangannya. Media yang dipilih adalah stiker scotlite glossy berwarna merah. Untuk proses pembuatan pola dan cutting, kami menggunakan jasa percetakan supaya lebih presisi dan meminimalisasi kesalahan.
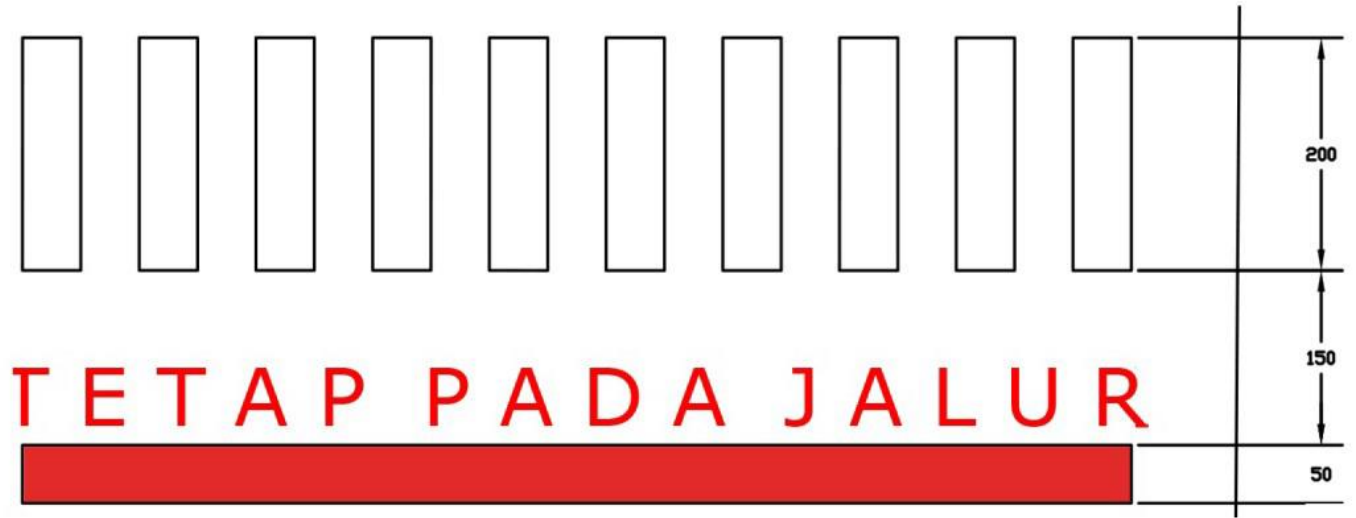

Gambar 8. Dimensi / Ukuran Kertas Stiker

Sumber: penulis, 2019

Sejalan dengan proses percetakan dan cutting, maka tim membuat simulasi desain dalam bentuk perspektif 3D menggunakan software sketchup, sehingga nantinya dapat membantu dan mempermudah tahapan pemasangan.

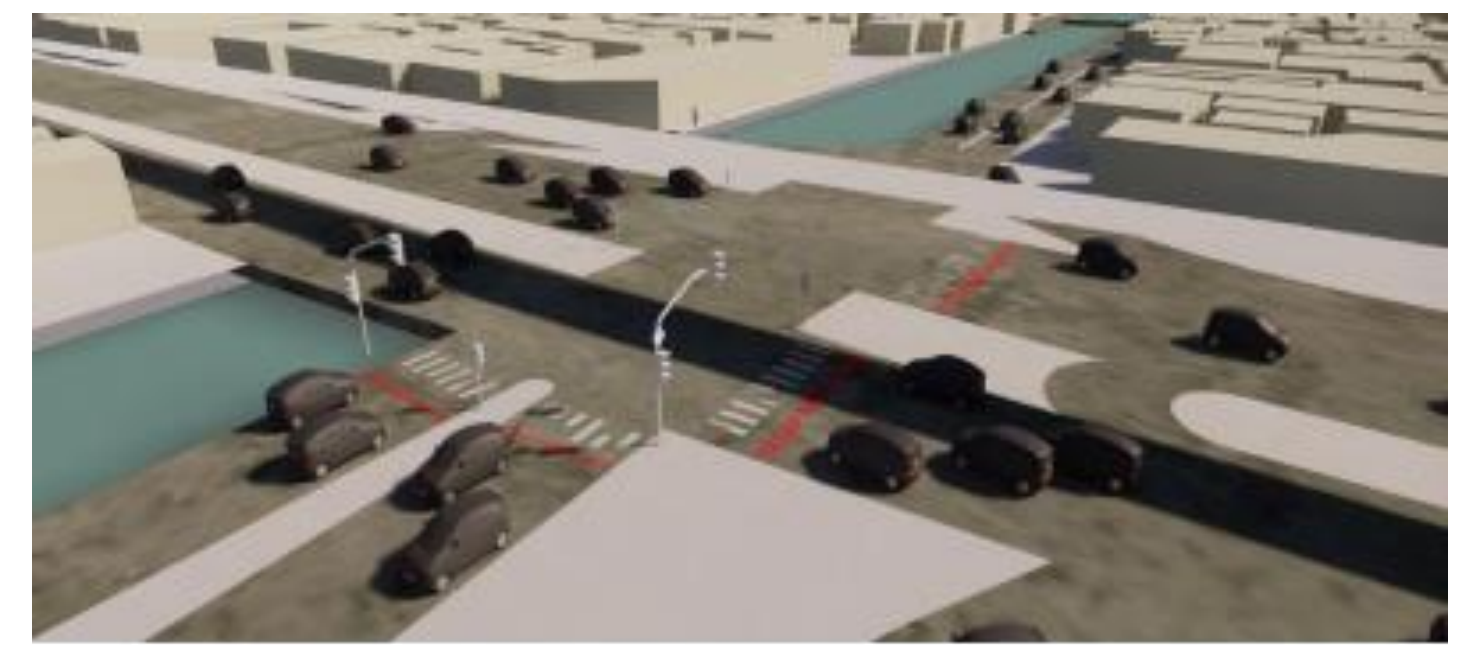

Gambar 9. Simulasi Perspektif Rambu Pada Perempatan Jl. Tubagus Angke

Sumber: penulis, 2019

\section{Pemasangan}

Pada tahap ini, tim pelaksanaa PKM yang terdiri dari dosen dan mahasiswa melakukan pemasangan desain di perempatan jalan dengan dibantu oleh personel polisi dari Polsek Tambora. 

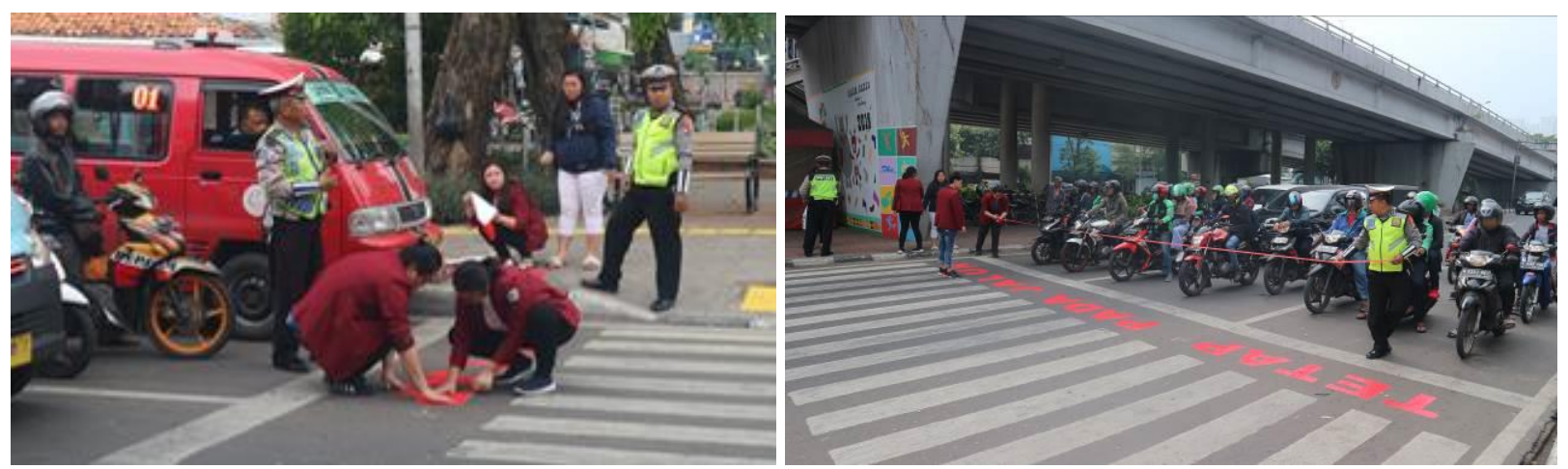

Gambar 10. Proses Pemasangan Rambu Pada Perempatan Jl. Tubagus Angke

Sumber: penulis, 2019

Setelah pemasangan tanda 'Tetap Pada Jalur' selesai, tim melakukan pengamatan untuk nantinya dijadikan bahan evaluasi. Pengamatan di lakukan selama 3 hari pada jam tertentu dimana terjadi paling banyak pelanggaran, yaitu pada saat jam berangkat kerja (07.00-09.00) dan pada sore hari pada saat pulang kantor $(16.00-18.00)$.
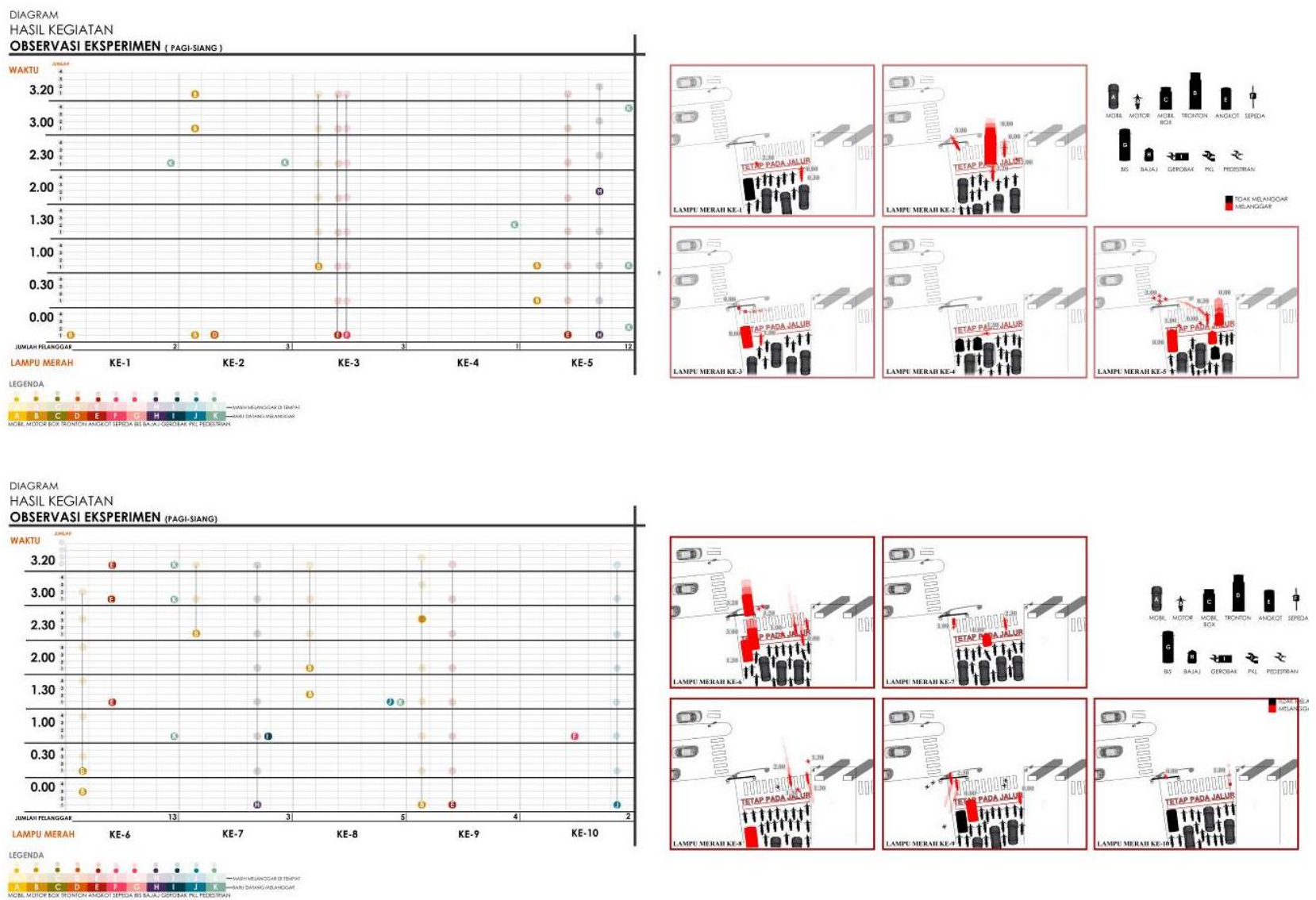

Gambar 11. Kondisi eksisting perempatan lampu merah Tubagus Angke pada saat lampu merah menyala, setelah pemasangan tanda 'Tetap Pada Jalur' (pengamatan jam 06.00-08.00)

Sumber: penulis, 2019 
DIAGRAM
HASILEGIATAN
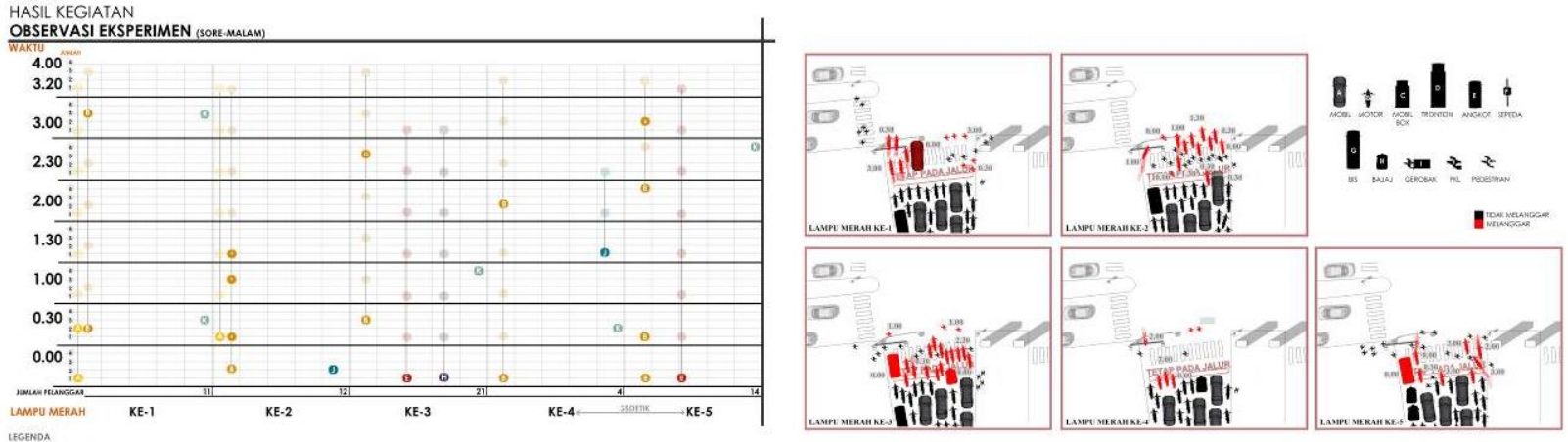

НGENDA.........

(a)

DIAGRAM
HASIL KEGIATAN
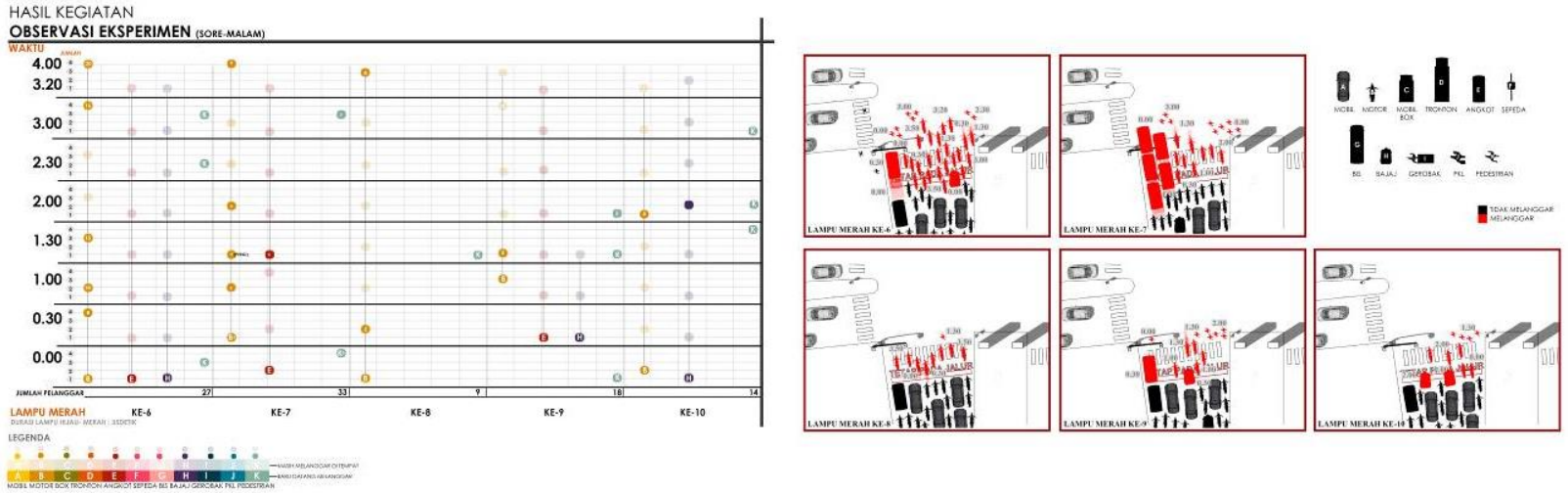

Gambar 12. Kondisi eksisting perempatan lampu merah Tubagus Angke pada saat lampu merah menyala, setelah pemasangan tanda 'Tetap Pada Jalur' (pengamatan jam 06.00-08.00)

Sumber: penulis, 2019
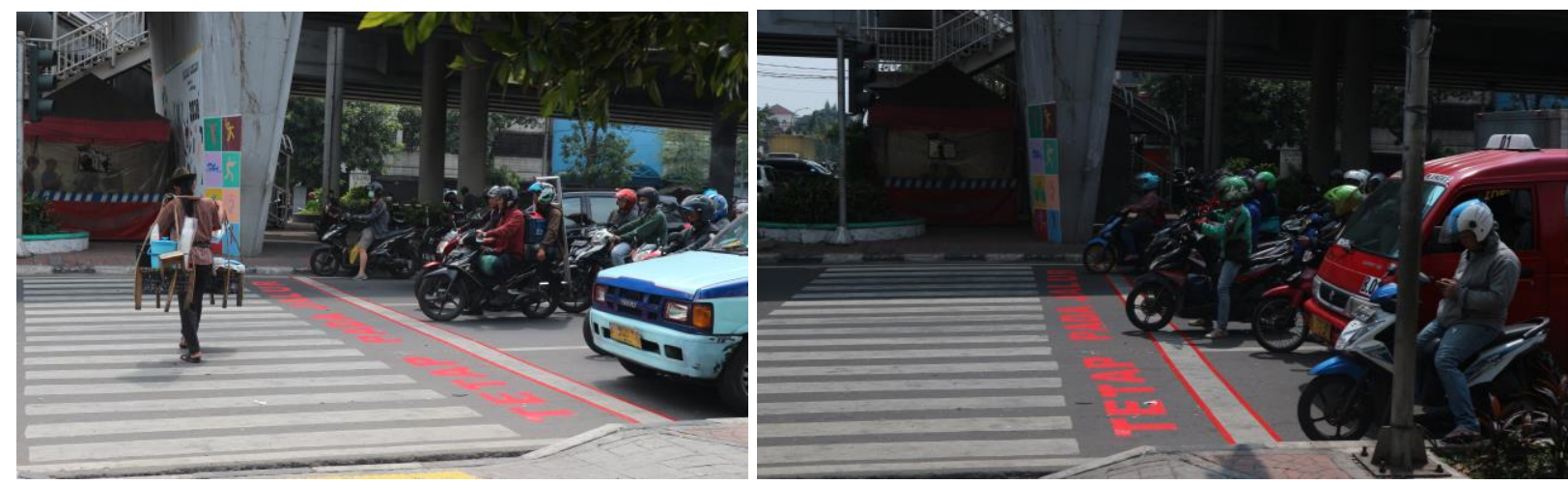

Gambar 13. Kondisi Eksisting setelah Pemasangan Rambu Pada Perempatan J1. Tubagus Angke Sumber: penulis, 2019

Berdasarkan hasil pengamatan, terjadi peningkatan perilaku tertib lalu lintas oleh pengguna jalan. Para pengguna kendaraan berhenti di belakang garis (meskipun ada beberapa pengendara motor yang masih berada digaris), sehingga ruang untuk pejalan kakipun menjadi lebih jelas batasannya. Hal tersebut nantinya akan berpengaruh terhadap penurunan kecelakaan lalu lintas yang terjadi di persimpangan jalan. Sebagai evaluasi, kedepannya perlu dipikirkan material yang lebih tahan lama serta bagaimana lampu jalan (pada malam hari) mempunyai pengaruh atau tidak terhadap warna merah.

Tahapan berikutnya sebagai pengembangan dari hasil PKM, hasil pengabdian ini dapat diobservasi lebih lanjut kedalam suatu bentuk penelitian tentang persepsi dan perilaku pengguna 
jalan terkait instalasi desain zebra cross tersebut, yang nantinya dapat dipublikasikan dalam bentuk jurnal ilmiah. Jika nantinya dalam penelitian tersebut terjadi perilaku yang positif dari pengguna jalan, maka desain ini dapat diduplikasi ke persimpangan jalan sejenis.

\section{KESIMPULAN}

Penyebab utama dalam suatu permasalahan pelanggaran zebra cross ini adalah kurang nya kesadaran dari pemilik kendaraan bermotor dan pengguna jalan, selain itu lemah nya hukum yang mengatur juga menjadi penyebab utama dari pelanggaran. Setelah berbicara mengenai perilaku para pengguna dan juga regulator di jalan ini maka ada hal lain yang turut mendukung terjadi nya pelanggaran zebra cross ini yaitu infrastruktur zebracross itu sendiri yang sudah tidak layak pakai, seperti hal nya warna nya yang memudar, kemudian warna yang dipakai kurang dapat merangsang para pengguna jalan, sampai kepada rusak nya jalan yang menghilangkan esensi zebracross sebagai tempat penyebrangan. Oleh karena itu pengabdian ini bertujuan untuk memperbaiki sistem dan desain pada zebracross, referensi desain baru dalam zebra cross ini bertujuan dalam menaikan tingkat kesadaran dan kepekaan masyarakat dalam menggunakan sarana publik ini, sehingga zebracross dapat digunakan secara tepat sasaran. Rancangan ulang zebracross ini dengan cara menggunakan material jalan yang lebih jelas dan berbeda dari jalan utama nya dan juga warna yang dipilih berwarna merah karena menurut penelitian dapat memmberikan rangsangan lebih untuk manusia agar dapat lebih dipatuhi, dan juga adanya tulisan himbauan dan peringatan untuk mematuhi zebracross yang di beri penebalan berwarna merah juga diharapkan dapat meningkatkan kesadaran pengguna kendaraan bermotor dan juga meningkatkan rasa aman untuk pengguna fasilitas penyebrangan ini. Berdasarkan hasil pengamatan yang dilakukan setelah pemasangan desain zebra cross, terjadi peningkatan perilaku tertib pengguna jalan, khususnya di perempatan jalan pada saat lampu merah menyala.

\section{Ucapan Terima Kasih}

Terima kasih kami ucapkan kepada:

1. Direktorat Peneltian dan Pengabdian kepada Masyarakat (DPPM) Universitas Tarumanagara, atas dukungan moral dan material sehingga pelaksanaan kegian PKM ini dapat dilaksanakan.

2. Polres Tambora, Jakarta Barat atas bantuan keamanan dalam pelaksanaan PKM

\section{REFERENSI}

Amelia, M.. 2018. Marka Pembatas Jalan Boleh Dicat Warna-Warni, Ini Aturannya.

Arifin, M. Z.; Prawito, G. S.; dan Ramadhan D.2007. Analisis Efektifitas Fasilitas Zebra cross Pada Jl. MT Haryono dan Jl. Gajayana. Malang.

Direktorat Jenderal Bina Marga, 1995. Tata Cara Perencanaan Fasilitas Pejalan Kaki di Kawasan Perkotaan. Jakarta.

Fransiska, Robet. 2013. Pengaruh Pencahayaan terhadap Psikologi.

Keputusan Direktur Jenderal Perhubungan Darat : SK.43/AJ 007/DRJD/97 Permenhub No 34 Tahun 2014

NRA, 2011. Pedestrian Crossing Specification and Guidance. Diambil dari http://www.tiipublications.ie/downloads/SRM/15-NRA-Pedestrian-Crossing.pdf 